\title{
Milk Conjugated Linoleic Acid Response to Fish Oil and Sunflower Oil Supplementation to Dairy Cows Managed Under Two Feeding Systems
}

\author{
A. A. AbuGhazaleh, ${ }^{*}$ D. O. Felton, ${ }^{*}$ and S. A. Ibrahim \\ *Department of Animal Science, Food and Nutrition, Southern Illinois University, Carbondale 62901 \\ †Department of Family and Consumer Sciences, North Carolina A\&T State University, Greensboro 27411
}

\begin{abstract}
Earlier research showed that conjugated linoleic acid (CLA) content in milk fat is highest when cows' diets are supplemented with a blend of fish oil (FO) and linoleic acid-rich oils. The objective of this study was to compare the effect of FO and sunflower oil (SFO) supplementation on milk cis-9, trans-11 CLA when dairy cows managed on pasture or in confinement. Fourteen Holstein cows were assigned into 2 treatment groups: cows grazed on alfalfa-grass pasture (PAS) or were fed corn silage-alfalfa hay mix ad libitum (LOT). Both groups were supplemented with a $8.2 \mathrm{~kg} / \mathrm{d}$ grain supplement containing $640 \mathrm{~g}$ of FO and SFO (1:3 wt/ wt). Grain supplement was fed in 2 equal portions after each milking, for a period of 3 wk. Milk samples were collected during the last $3 \mathrm{~d}$ of the experimental period. Milk yield was greater with the LOT diet $(23.1 \mathrm{~kg} /$ d) compared with the PAS diet $(19.4 \mathrm{~kg} / \mathrm{d})$. Milk fat percentages (2.51 and 2.95 for the LOT and PAS, respectively) and yields $(0.57$ and $0.51 \mathrm{~kg} / \mathrm{d})$ were similar for the 2 diets. Milk protein percentages were not affected by diets (3.34 and 3.35 for the LOT and PAS diets, respectively), but protein yields were lower for the PAS $\operatorname{diet}(0.61 \mathrm{~kg} / \mathrm{d})$ compared with the LOT diet $(0.75 \mathrm{~kg} /$ d). Treatment diets had no effect on milk trans C18:1 concentrations [10.64 and $9.82 \mathrm{~g} / 100 \mathrm{~g}$ of total fatty acids (FA) for the LOT and PAS, respectively] or yields (60.65 and $64.01 \mathrm{~g} / \mathrm{d})$, but did affect isomers distributions. Concentration ( $\mathrm{g} / 100 \mathrm{~g}$ of total FA) of vaccenic acid was lower with the LOT diet (2.15) compared with the PAS diet (4.52), whereas concentration of trans-10 C18:1 was greater with the LOT diet (4.99) compared with the PAS diet (1.69). Milk cis-9, trans-11 CLA concentration was greater with the PAS diet (1.52) compared with the LOT diet (0.84). In conclusion, the increase in milk cis-9, trans-11 CLA content was greater when pasture-based diets were supplemented with FO
\end{abstract}

Received March 2, 2007.

Accepted June 22, 2007.

${ }^{1}$ Corresponding author: aabugha@siu.edu and SFO. The lower cis-9, trans-11 CLA concentration in milk from the confinement-fed cows resulted from trans-10 C18:1 replacing vaccenic acid as the predominant trans C18:1 isomer.

Key words: forage source, fish oil, sunflower oil, milk conjugated linoleic acid

\section{INTRODUCTION}

Conjugated linoleic acid (CLA) is a collective term for positional and geometric isomers of linoleic acid (C18:2) in which the 2 double bonds are conjugated rather than separated by a methyl group. Due to the fact that the double bonds are present at various positions on the 18-carbon chain of the molecule and can have the cis and trans geometry, numerous different CLA are possible. Following reports (Sehat et al., 1998) that cis-9, trans-11 CLA, the major CLA isomer in milk fat, inhibits the growth of a number of human cancer cell lines and suppresses chemically induced tumors development in animal models (Parodi, 1999), there has been growing interest in developing dairy products enriched with cis-9, trans-11 CLA.

The cis-9, trans-11 CLA is formed in the rumen as an intermediate in the biohydrogenation of linoleic acid or in tissues by $\Delta^{9}$-desaturase from vaccenic acid (VA, trans-11 C18:1), another intermediate in the ruminal biohydrogenation of oleic, linoleic, and linolenic acids (Griinari and Bauman, 1999; AbuGhazaleh et al., 2005). Recent studies (Piperova et al., 2002; Kay et al., 2004) have estimated that more than $90 \%$ of milk cis9 , trans-11 CLA is made by the activity of the $\Delta^{9}$-desaturase enzyme.

Cows on pasture diets have been shown to have higher concentrations of CLA (Kelly et al., 1998; Lawless et al., 1998; White et al., 2001; Boken et al., 2005) in their milk than those consuming conserved forages. It also has been shown that milk CLA concentration can be enhanced in pasture grazing cows when their feed is supplemented with oils (Lawless et al., 1998; Boken et al., 2005; AbuGhazaleh and Holmes, 2007). Lawless et al. (1998) found that supplementation of grazing cows with full-fat soybeans or full-fat rapeseeds 
increased milk CLA concentration by 24.3 and $61 \%$, respectively, relative to controls. Schroeder et al. (2003) reported that compared with grazing cows receiving corn-based concentrate, milk CLA increased by $173 \%$ when Ca-salts of fatty acids (FA; 30\% linoleic acid) partially replaced corn grain. Cows grazing on annual rye-ryegrass pasture supplemented with a grain mix containing $500 \mathrm{~g} / \mathrm{d}$ of soybean oil had the CLA content in milk increased by $46 \%$ compared with cows not supplemented with oil (Boken et al., 2005).

Inclusion of fish oil (FO) in TMR is an effective means of increasing milk cis-9, trans-11 CLA content (Donovan et al., 2000; Whitlock et al., 2002). This appears to occur because of the inhibitory effect of docosahexaenoic acid $(\mathrm{C} 22: 6 \mathrm{n} 3)$ in $\mathrm{FO}$ on VA reduction to stearic acid (AbuGhazaleh and Jenkins, 2004). Milk cis-9, trans-11 CLA response to FO is further enhanced when given in combination with linoleic or linolenic acid-rich oil sources (AbuGhazaleh et al., 2002, 2003). AbuGhazaleh et al. (2003) concluded that supplementing dairy cows' diets with a combination of FO and linoleic acid-rich oils is the most effective dietary regimen to increase milk cis9, trans-11 CLA content. Despite the volume of research on the impact of dietary FO and plant oils on milk's cis-9, trans-11 CLA content, there are surprisingly few data in the literature evaluating the effect that dietary oil supplements may have under different feeding systems (pasture vs. confinement) on cis-9, trans-11 CLA content. Therefore, the objective of this study was to compare milk cis-9, trans-11 CLA response in cows managed on pasture or in confinement when supplemented with a blend of FO and sunflower oil (SFO).

\section{MATERIALS AND METHODS}

Fourteen multiparous Holstein cows, selected from the herd of Southern Illinois University Dairy Cattle Research Center (Carbondale, IL), were used in a 5wk study between August and September of 2006. All procedures for this study were conducted under approval of the Southern Illinois University Institutional Animal Care and Use Committee. During the first 2 wk (preexperiment), cows were housed in a free-stall barn and fed corn silage-alfalfa hay mix (65:35; DM basis) ad libitum plus $8.2 \mathrm{~kg} / \mathrm{d}$ of basal grain supplement. The basal grain supplement contained (DM basis) $51 \%$ cracked corn, $29 \%$ soybean meal, $10 \%$ dried molasses, $5 \%$ meat and bone meal, $3.0 \%$ limestone, $1.5 \%$ dicalcium phosphate, and $1.5 \%$ vitamins and minerals (vitamin ADE premix, vitamin E premix, magnesium oxide, and high zinc trace mineralized salt). Milk production was recorded daily and milk samples were taken from each cow during the last $3 \mathrm{~d}(0600$ and $1800 \mathrm{~h})$ of wk 2 for composition and FA analysis. Milk production and composition data generated during these 2 wk were used for covariance analysis. At the start of wk 3, cows were paired according to milk yield $(24.3 \pm 3.7 \mathrm{~kg} / \mathrm{d})$ and DIM (195 \pm 18$)$ and randomly assigned into 2 treatment groups using a complete randomized design with a 21-d experimental period. The first $18 \mathrm{~d}$ of the experimental period were used for adjustments to diets, and the last $3 \mathrm{~d}$ for data collections. Cows in group 1 remained on confinement and kept receiving the corn silage-alfalfa hay mix ad libitum (LOT), whereas cows in group 2 grazed on alfalfa-grass pasture (PAS). Both groups also received an $8.2-\mathrm{kg} / \mathrm{d}$ grain supplement containing 640 $\mathrm{g}$ of FO and SFO (1:3 wt/wt). The grain supplement contained (DM basis) $44.2 \%$ cracked corn, $27.1 \%$ soybean meal, $9.8 \%$ dried molasses, $6.4 \%$ SFO, $2.1 \%$ FO, $3.9 \%$ meat and bone meal, $3.3 \%$ limestone, $1.6 \%$ dicalcium phosphate, $0.7 \%$ high zinc trace mineralized salt, $0.3 \%$ magnesium oxide, $0.3 \%$ vitamin $\mathrm{E}$ premix, and $0.3 \%$ vitamin ADE premix. Menhaden FO (Omega Protein Inc., Hammond, LA) and SFO (purchased from a local dealer) were used in this study. Cows on pasture grazed together under intensive rotational grazing management. The pasture was diverse and consisted of alfalfa, orchardgrass, fescue, and weeds (35:35:15:15 $\mathrm{wt} / \mathrm{wt}$ ). The pasture area was divided into twenty-one 1acre paddocks, and cows were moved to a new paddock daily. Polywire fencing prevented cows from grazing the next paddock or the previously grazed areas. Cows had free access to water. Grain supplement was offered in 2 equal portions after the morning and afternoon milking in the barn using Calan Broadbent feeder doors (American Calan Inc., Northwood, NH) for individual feed intakes. Amounts of grain supplement offered and orts were recorded daily for individual cows. Cows remained on the pasture daily for about $21 \mathrm{~h}$.

Cows were milked twice daily at 0600 and $1800 \mathrm{~h}$ during the study, with individual milk weights recorded at each milking. Milk from individual cows was sampled during three 24 -h periods on the last $3 \mathrm{~d}$ of the experiment and made into daily composites, amounts proportional to milk yield at each time. Composites were divided into 2 aliquots for analyses. One was refrigerated at $4^{\circ} \mathrm{C}$ and sent to Prairie Farms (Carlinville, IL) for analysis of fat, protein, lactose, and total solids (AOAC, 1997) by midinfrared spectrophotometry and SCC (AOAC, 1997) using a Fossomatic 90 (Prairie Farms). The second sample was stored at $-20^{\circ} \mathrm{C}$ until analysis for FA composition. Representative pasture forage samples were collected on the last day of each week before grazing at 6 different locations per 1 acre using a 0.50 $\mathrm{m}^{2}$ quadrat. The plants were clipped to a $2.5-\mathrm{cm}$ stubble height using metal shears. Pasture samples were composited per week and stored at $-20^{\circ} \mathrm{C}$ until analysis for chemical and FA composition. On the last day of each 
week, samples of grain supplement, corn silage, and alfalfa hay were collected for analyses.

Pasture forage, corn silage, alfalfa hay, and grain supplement were freeze dried (Labconco Freeze Dry System, Labconco, Kansas City, MO) and then grounded through a standard model No. 3 Wiley mill (Arthur H. Thomas Co., Philadelphia, PA) with a 2-mm screen. Samples were analyzed for CP, ether extract, and ash according to AOAC methods (1997). Samples were reground (Brinkman ultracentrifuge mill) through a 1-mm screen prior to analyses for FA (Kramer et al., 1997) and fiber. Neutral detergent fiber (procedure B of Van Soest et al., 1991) and ADF (Robertson and Van Soest, 1981) were determined by Ankom fiber analyzer using the filter bag technique (Ankom Technology Corp., Fairport, NY). Body weights and BCS were recorded at the beginning and end of the study.

Milk and feed samples were methylated using the 2step procedure outlined by Kramer et al. (1997). Milk samples were thawed in a $35^{\circ} \mathrm{C}$ water bath, and $1 \mathrm{~mL}$ was transferred into a glass test tube $(16 \times 200 \mathrm{~mm})$ with Teflon-lined screw cap, stored at $-80^{\circ} \mathrm{C}$ for $6 \mathrm{~h}$, freeze dried, and then methylated. Methylated samples were then analyzed for FA using a Shimadzu GC-2010 gas chromatograph (Shimadzu Scientific Instruments Inc., Columbia, MD) equipped with a flame ionization detector and a Supelco 100-m SP-2560 fused-silica capillary column $(0.25 \mathrm{~mm}$ i.d. $\times 0.2 \mu \mathrm{m}$ film thickness $)$. The helium carrier gas was maintained at a linear velocity of $23 \mathrm{~cm} / \mathrm{s}$. The oven temperature was programmed for $135^{\circ} \mathrm{C}$ for $5 \mathrm{~min}$, then increased at $5^{\circ} \mathrm{C} /$ min to $165^{\circ} \mathrm{C}$, held there for $80 \mathrm{~min}$, then increased at $1.5^{\circ} \mathrm{C} / \mathrm{min}$ to $180^{\circ} \mathrm{C}$, then increased at $5^{\circ} \mathrm{C} / \mathrm{min}$ to $245^{\circ} \mathrm{C}$ and held there for $9 \mathrm{~min}$. Peaks were identified by comparing the retention times with FA in the corresponding standards (Nu-Chek Prep, Elysian, MN; Supelco, Bellefonte, PA; and Larodan Fine Chemicals, Malmo, Sweden).

The ANOVA was conducted using the MIXED procedure of SAS for a complete randomized design. The model contained the effects of diet, sample, and covariate. Cow within diet was used as an error term. Least squares means are reported throughout, and significance was declared at $P<0.05$.

\section{RESULTS AND DISCUSSION}

The FA and nutrient compositions for the grain supplement, pasture, corn silage, and alfalfa hay are presented in Table 1. Oleic acid was the major FA in grain supplement, and it accounted for $45.6 \%$ of total FA, whereas linoleic acid accounted only for $24.9 \%$ of total FA. The unexpected high oleic acid concentration found in the grain supplement was due to high oleic levels from the sunflower seed oil. Linoleic acid accounts for $70 \%$ of total FA in typical SFO (Casper et al., 1988) compared with $28 \%$ in our SFO supplement (Table 1). As expected, linolenic acid was the major FA in pasture (40.5\% of total FA), whereas linoleic acid was the major FA in corn silage (48.5\% of total FA). Linoleic and linolenic acids accounted for 24.4 and $23.2 \%$ of alfalfa hay total FA. The high NDF and ADF values for the pasture reflect its advanced phenological stage.

The effect of feeding systems on milk yield and composition is presented in Table 2. Compared with the LOT diet, the PAS diet resulted in a reduction $(P<0.05)$ in milk yield. By the end of the study, cows on the PAS diet produced $3.7 \mathrm{~kg} / \mathrm{d}$ less milk than cows in the LOT diet. Reduction in milk yield is consistently seen in cows managed on pasture compared with cows managed in confinement (White et al., 2001; Bargo et al., 2002, 2006; Boken et al., 2005). Bargo et al. (2006) reported that cows kept on pasture for $19 \mathrm{wk}$ and supplemented with grain mix ( $1 \mathrm{~kg} / 4 \mathrm{~kg}$ of milk yield) produced 9.6 $\mathrm{kg} / \mathrm{d}$ less milk than cows fed TMR. Additionally, when cows were managed under 2 different feeding systems (confinement vs. pasture) and fed oil supplement for 14-wk, Boken et al. (2005) reported that cows on pasture produced $5.8 \mathrm{~kg} / \mathrm{d}$ less milk than cows in confinement.

Milk fat percentages (2.51 and 2.95 for the LOT and PAS, respectively) and yields $(0.57$ and $0.51 \mathrm{~kg} / \mathrm{d})$ were similar $(P>0.05)$ for the 2 diets. Milk protein percentages were not affected $(P>0.05)$ by diets averaging 3.34 and 3.35 for the LOT and the PAS diets, respectively. Boken et al. (2005) reported no difference in milk protein content between cows fed soybean oil and managed in confinement or on pasture. Recently, Holmes and AbuGhazaleh (2007) also observed no effect on milk protein content when equal amounts of linseed oil and FO were fed to cows managed under confinement or pasture feeding systems. Production of milk protein was lower $(P<0.05)$ with the PAS diet $(0.61 \mathrm{~kg} / \mathrm{d}) \mathrm{com}$ pared with the LOT diet $(0.75 \mathrm{~kg} / \mathrm{d})$ as a result of lower milk yield with the PAS diet (Table 2). There were no differences in milk lactose, SCC, BW, BCS, and grain supplement intake between the 2 feeding groups (Table 2).

The effect of feeding systems on milk FA concentrations and yields is presented in Tables 3 and 4. Milk trans $\mathrm{C} 18: 1$ concentrations (10.61 and $9.87 \mathrm{~g} / 100 \mathrm{~g}$ of total FA for the LOT and PAS, respectively) and yields $(60.65$ and $64.01 \mathrm{~g} / \mathrm{d})$ were similar $(P>0.05)$ for both diets. Holmes and AbuGhazaleh (2007) also reported no differences in milk trans C18:1 when a blend of FO and linseed oil was fed to cows on pasture or in confinement. Even though milk trans C18:1 concentrations and yields were similar for the 2 diets, the distributions of individual isomers differed. The concentrations of 
Table 1. Fatty acid and nutrient compositions for grain supplement, pasture, forages, and oil supplements

\begin{tabular}{|c|c|c|c|c|c|c|}
\hline Fatty acid & $\begin{array}{c}\text { Grain } \\
\text { supplement }^{1}\end{array}$ & Pasture $^{2}$ & $\begin{array}{c}\text { Alfalfa } \\
\text { hay }\end{array}$ & $\begin{array}{l}\text { Corn } \\
\text { silage }\end{array}$ & $\begin{array}{l}\text { Sunflower } \\
\text { oil }\end{array}$ & $\begin{array}{c}\text { Fish } \\
\text { oil }\end{array}$ \\
\hline C14:0 & 1.82 & 0.58 & 0.70 & 0.34 & 0.10 & 6.79 \\
\hline C16:0 & 9.72 & 13.95 & 29.98 & 16.59 & 4.76 & 16.67 \\
\hline C18:0 & 4.16 & 1.72 & 6.03 & 2.93 & 3.55 & 3.41 \\
\hline C18:1 cis-9 & 45.60 & 3.52 & 8.01 & 18.76 & 61.82 & 9.22 \\
\hline C18:2 cis-9, cis-12 & 24.86 & 15.65 & 24.43 & 48.50 & 27.89 & 1.13 \\
\hline C18:3n-3 & 0.73 & 40.53 & 23.15 & 11.09 & 0.10 & 1.49 \\
\hline C20:5n-3 & 1.90 & $\mathrm{ND}^{3}$ & ND & ND & ND & 10.72 \\
\hline $\mathrm{C} 22: 6 \mathrm{n}-3$ & 2.03 & 0.27 & ND & ND & ND & 13.15 \\
\hline \multicolumn{7}{|c|}{ Composition, \% of DM } \\
\hline $\mathrm{NE}_{\mathrm{L}},{ }^{4} \mathrm{Mcal} / \mathrm{kg}$ & 2.09 & & & & & \\
\hline $\mathrm{CP}$ & 26.63 & 20.16 & 15.27 & 8.28 & & \\
\hline $\mathrm{NDF}$ & 16.03 & 61.39 & 56.74 & 51.36 & & \\
\hline $\mathrm{ADF}$ & 12.04 & 42.85 & 30.10 & 30.37 & & \\
\hline Fatty acids & 9.24 & 0.98 & 1.13 & 1.21 & & \\
\hline
\end{tabular}

${ }^{1}$ Grain supplement $=$ contained $640 \mathrm{~g}$ of fish oil and sunflower oil $(1: 3 \mathrm{wt} / \mathrm{wt})$.

${ }^{2}$ Pasture $=35: 35: 20: 10$ alfalfa:orchard grass:fescue:weeds.

${ }^{3} \mathrm{ND}=$ not detected or detected at $<0.01$.

${ }^{4} \mathrm{NE}_{\mathrm{L}}=$ estimated NRC (2001).

milk VA and trans-16 were higher $(P<0.05)$ with the PAS diet than with the LOT diet, but the concentration of trans-10 was higher $(P<0.05)$ with the LOT diet than the PAS diet (Table 3). Vaccenic acid and trans-10 C18:1 were still the predominant trans $\mathrm{C} 18: 1$ isomers in both diets accounting for 20 and $47 \%$ of trans C18:1 isomers in the LOT diet and 46 and $17 \%$ in the PAS diet, respectively. To the author's knowledge, there are no published data comparing the effect of dietary oil supplementations under pasture and confinement feed-

Table 2. Effect of treatment diets on milk yield, milk composition, and grain intake

\begin{tabular}{lccc}
\hline & \multicolumn{2}{c}{ Diet $^{1}$} & \\
\cline { 2 - 3 } Item & LOT & PAS & SEM \\
\hline Milk yield, kg/d & $23.10^{\mathrm{a}}$ & $19.60^{\mathrm{b}}$ & 1.351 \\
Concentration $(\mathrm{g} / \mathrm{kg})$ & & & \\
Fat & 2.51 & 2.95 & 0.254 \\
Protein & 3.34 & 3.35 & 0.220 \\
Lactose & 4.45 & 4.51 & 0.096 \\
TS & 11.29 & 11.65 & 0.450 \\
Yield (kg/d) & & & \\
Fat & 0.57 & 0.51 & 0.063 \\
Protein & $0.75^{\mathrm{a}}$ & $0.61^{\mathrm{b}}$ & 0.048 \\
Lactose & 1.02 & 0.88 & 0.115 \\
TS & 2.52 & 2.21 & 0.172 \\
SCC, $\times 10^{3} / \mathrm{mL}$ & 424 & 329 & 66 \\
BW, kg & 580 & 613 & 34 \\
BCS ${ }^{2}$ & 2.82 & 2.77 & 0.140 \\
Grain supplement intake, kg/d & 8.19 & 8.18 & 0.015 \\
\hline
\end{tabular}

\footnotetext{
${ }^{\mathrm{a}, \mathrm{b}}$ Means in the same row with different superscripts differ $(P<$ 0.05).

${ }^{1} \mathrm{LOT}=$ corn silage-alfalfa hay mix plus $640 \mathrm{~g}$ of fish oil and sunflower oil (1:3 wt/wt); PAS = pasture plus $640 \mathrm{~g}$ of fish oil and sunflower oil (1:3 wt/wt).

${ }^{2}$ Scored on a 5 -point scale, where $1=$ emaciated to $5=$ fat.
}

ing systems on the distributions of milk trans C18:1 isomers. Milk concentrations of VA increased and trans$10 \mathrm{C} 18: 1$ decreased in a linear manner as the proportion of fresh grass in the diet of lactating cows increased (Couvreur et al., 2006). Kay et al. (2005) reported that trans-10 C18:1 contributed $<1 \%$ of the milk total FA in pasture-fed cows compared with about $25 \%$ in TMR fed cows. Furthermore, Loor et al. (2003) reported higher trans-10 C18:1 in milk of cows fed TMR compared with TMR plus pasture. Results from previous studies (Shingfield et al., 2005; AbuGhazaleh and Jacobson, 2007) suggest that diets that promote low ruminal $\mathrm{pH}$ (e.g., high starch intake) increase trans-10 C18:1 production in the rumen at the expenses of VA. trans-10 C18:1 in milk fat increased as the ratio of corn to alfalfa silage in the diet varied from 25 to $50 \%$ of diet DM and was further enhanced by lipid supplementation (Onetti et al., 2002). In this study, it appears that the intake of corn silage by the LOT cows may have provided ruminal conditions (low $\mathrm{pH}$ ) favoring a shift in the biohydrogenation pathways toward more trans-10 C18:1 synthesis, possibly as a result of alteration in the microbial community profile, enzyme activities, or both. The concentrations of trans-6/8, trans-9, and trans-12 C18:1 were similar $(P>0.05)$ for the 2 diets, averaging 9.7, 8.3, and $12.5 \%$ of milk trans C18:1, respectively.

The main objective of this study was to compare milk cis-9, trans-11 CLA response to feeding a CLA-stimulating diet under pasture or confinement feeding systems. Even though the intake of supplemental oil was similar for both diets, the concentrations and yields of milk total CLA were higher $(P<0.05)$ for cows on the PAS diet $(1.61 \mathrm{~g} / 100 \mathrm{~g}$ of total FA and $7.93 \mathrm{~g} / \mathrm{d})$ than the LOT diet $(0.87 \mathrm{~g} / 100 \mathrm{~g}$ of total FA and $4.93 \mathrm{~g} / \mathrm{d})$. In both 
Table 3. Effect of treatment diets on milk fatty acid composition ( $\mathrm{g} /$ $100 \mathrm{~g}$ of fatty acids)

\begin{tabular}{|c|c|c|c|}
\hline \multirow[b]{2}{*}{ Fatty acid } & \multicolumn{2}{|c|}{$\operatorname{Diet}^{1}$} & \multirow[b]{2}{*}{ SEM } \\
\hline & LOT & PAS & \\
\hline $\mathrm{C} 4: 0$ & 1.34 & 1.23 & 0.112 \\
\hline C6:0 & 1.10 & 0.99 & 0.070 \\
\hline C8:0 & 0.62 & 0.53 & 0.038 \\
\hline $\mathrm{C} 10: 0$ & $1.27^{\mathrm{a}}$ & $0.99^{\mathrm{b}}$ & 0.075 \\
\hline C12:0 & 1.68 & 1.26 & 0.080 \\
\hline C14:0 & $8.18^{\mathrm{a}}$ & $6.56^{\mathrm{b}}$ & 0.296 \\
\hline C14:1 & 0.91 & 0.76 & 0.106 \\
\hline $\mathrm{C} 15: 0$ & 0.82 & 0.83 & 0.031 \\
\hline C16:0 & 23.81 & 22.17 & 0.915 \\
\hline C16:1 & 1.78 & 1.70 & 0.188 \\
\hline $\mathrm{C} 17: 0$ & 0.48 & 0.52 & 0.021 \\
\hline C18:0 & 9.89 & 11.31 & 0.920 \\
\hline C18:1 cis-9 & $23.14^{\mathrm{b}}$ & $27.06^{\mathrm{a}}$ & 0.786 \\
\hline C18:1 cis-11 & $0.98^{\mathrm{a}}$ & $0.85^{\mathrm{b}}$ & 0.041 \\
\hline C18:1 cis-12 & $0.34^{\mathrm{a}}$ & $0.28^{\mathrm{b}}$ & 0.020 \\
\hline C18:1 trans & 10.61 & 9.87 & 0.652 \\
\hline trans $-6 / 8$ & 0.99 & 1.00 & 0.073 \\
\hline trans -9 & 0.80 & 0.89 & 0.042 \\
\hline trans -10 & $4.99^{\mathrm{a}}$ & $1.69^{b}$ & 0.409 \\
\hline trans -11 & $2.15^{\mathrm{b}}$ & $4.53^{\mathrm{a}}$ & 0.385 \\
\hline trans -12 & 1.33 & 1.22 & 0.052 \\
\hline trans -16 & $0.37^{\mathrm{b}}$ & $0.49^{\mathrm{a}}$ & 0.025 \\
\hline $\mathrm{C} 18: 2$ cis- 9, cis-12 & $2.32^{\mathrm{a}}$ & $1.80^{\mathrm{b}}$ & 0.105 \\
\hline C18:2 cis-9, trans-12 & $0.12^{\mathrm{b}}$ & $0.15^{\mathrm{a}}$ & 0.011 \\
\hline $\mathrm{C} 18: 2$ trans -9, cis- 12 & 0.02 & 0.03 & 0.007 \\
\hline $\mathrm{C} 18: 2$ trans -9, trans -12 & 0.01 & 0.01 & 0.002 \\
\hline C18:2 trans -11, cis- 15 & $0.14^{\mathrm{b}}$ & $0.23^{\mathrm{a}}$ & 0.018 \\
\hline CLA & $0.87^{b}$ & $1.61^{\mathrm{a}}$ & 0.178 \\
\hline cis -9, trans -11 & $0.84^{\mathrm{b}}$ & $1.53^{\mathrm{a}}$ & 0.133 \\
\hline cis -10, cis -12 & 0.01 & 0.01 & 0.003 \\
\hline trans -10, cis -12 & $\mathrm{ND}^{2}$ & 0.01 & 0.002 \\
\hline trans, trans & $0.03^{\mathrm{b}}$ & $0.07^{\mathrm{a}}$ & 0.014 \\
\hline $18: 3 n-3$ & 0.16 & 0.16 & 0.015 \\
\hline C18:3n-6 & 0.01 & 0.01 & 0.003 \\
\hline $\mathrm{C} 18: 4 \mathrm{n}-3$ & 0.01 & 0.02 & 0.004 \\
\hline $\mathrm{C} 20: 0$ & $0.17^{b}$ & $0.24^{\mathrm{a}}$ & 0.022 \\
\hline C20:1 & 0.03 & 0.01 & 0.008 \\
\hline $\mathrm{C} 20: 2$ & 0.01 & 0.02 & 0.005 \\
\hline C20:4 & 0.05 & 0.04 & 0.005 \\
\hline C20:5n-3 & 0.04 & 0.03 & 0.006 \\
\hline C22:2 & 0.02 & 0.01 & 0.004 \\
\hline C22:3n-3 & 0.02 & 0.01 & 0.003 \\
\hline $\mathrm{C} 22: 4$ & 0.12 & 0.12 & 0.016 \\
\hline $\mathrm{C} 22: 5 \mathrm{n}-3$ & 0.07 & 0.06 & 0.004 \\
\hline C22:6n-3 & 0.05 & 0.04 & 0.004 \\
\hline
\end{tabular}

${ }^{\mathrm{a}, \mathrm{b}}$ Means in the same row with different superscripts $\operatorname{differ}(P<$ $0.05)$.

${ }^{1} \mathrm{LOT}=$ corn silage-alfalfa hay mix plus $640 \mathrm{~g}$ of fish oil and sunflower oil (1:3 wt/wt); $\mathrm{PAS}=$ pasture plus $640 \mathrm{~g}$ of fish oil and sunflower oil (1:3 wt/wt).

${ }^{2} \mathrm{ND}=$ not detected or detected at $<0.01$.

diets, the predominant CLA isomer was cis-9, trans-11 CLA accounting for 95 and $94 \%$ of total CLA in the LOT and the PAS diets, respectively. Milk cis-9, trans11 CLA concentration and yield were 81 and $60 \%$, respectively, higher with the PAS diet than the LOT diet. Concentration of cis-9, trans-11 CLA is usually higher in milk fat from cows fed fresh forages compared with conserved forages (White et al., 2001; Boken et al., 2005;
Table 4. Effect of treatment diets on milk fatty acid yield (g/d)

\begin{tabular}{|c|c|c|c|}
\hline \multirow[b]{2}{*}{ Fatty acid } & \multicolumn{2}{|c|}{$\operatorname{Diet}^{1}$} & \multirow[b]{2}{*}{ SEM } \\
\hline & LOT & PAS & \\
\hline $\mathrm{C} 4: 0$ & 7.44 & 7.16 & 0.176 \\
\hline C6:0 & 6.14 & 5.61 & 0.936 \\
\hline $\mathrm{C} 8: 0$ & 3.55 & 2.87 & 0.511 \\
\hline C10:0 & 7.26 & 5.27 & 0.935 \\
\hline $\mathrm{C} 12: 0$ & 9.44 & 6.57 & 0.992 \\
\hline C14:0 & 45.70 & 33.94 & 4.388 \\
\hline $\mathrm{C} 14: 1$ & 5.11 & 3.64 & 0.605 \\
\hline C15:0 & 4.57 & 4.28 & 0.471 \\
\hline $\mathrm{C} 16: 0$ & 131.85 & 114.49 & 12.699 \\
\hline C16:1 & 9.50 & 8.26 & 0.765 \\
\hline $\mathrm{C} 17: 0$ & 2.97 & 2.6 & 0.404 \\
\hline C18:0 & 58.36 & 60.35 & 11.084 \\
\hline C18:1 cis-9 & 132.84 & 139.00 & 13.116 \\
\hline C18:1 cis-11 & 5.18 & 4.71 & 0.384 \\
\hline C18:1 cis-12 & 1.86 & 1.47 & 0.185 \\
\hline C18:1 trans & 60.65 & 64.01 & 7.530 \\
\hline trans $-6 / 8$ & 5.76 & 4.88 & 0.623 \\
\hline trans -9 & 4.49 & 4.44 & 0.350 \\
\hline trans -10 & $27.86^{\mathrm{a}}$ & $8.71^{\mathrm{b}}$ & 3.252 \\
\hline trans -11 & $13.35^{\mathrm{b}}$ & $23.10^{\mathrm{a}}$ & 2.910 \\
\hline trans -12 & 7.62 & 6.23 & 0.797 \\
\hline trans -16 & 2.13 & 2.62 & 0.360 \\
\hline $\mathrm{C} 18: 2$ cis-9, cis-12 & $13.31^{\mathrm{a}}$ & $9.39^{b}$ & 1.387 \\
\hline C18:2 cis-9, trans-12 & 0.63 & 0.76 & 0.053 \\
\hline $\mathrm{C} 18: 2$ trans -9, cis -12 & 0.15 & 0.16 & 0.062 \\
\hline $\mathrm{C} 18: 2$ trans -9, trans -12 & 0.04 & 0.03 & 0.009 \\
\hline $\mathrm{C} 18: 2$ trans -11, cis -15 & 0.93 & 1.12 & 0.146 \\
\hline CLA & $4.93^{\mathrm{b}}$ & $7.93^{\mathrm{a}}$ & 0.787 \\
\hline cis -9, trans -11 & $4.69^{\mathrm{b}}$ & $7.50^{\mathrm{a}}$ & 0.759 \\
\hline cis -10, cis -12 & 0.04 & 0.06 & 0.013 \\
\hline trans -10, cis -12 & 0.02 & 0.03 & 0.012 \\
\hline trans, trans & $0.15^{\mathrm{b}}$ & $0.32^{\mathrm{a}}$ & 0.062 \\
\hline $18: 3 n-3$ & 0.93 & 0.84 & 0.16 \\
\hline C18:3n-6 & 0.03 & 0.05 & 0.015 \\
\hline C18:4n-3 & 0.04 & 0.07 & 0.018 \\
\hline C20:0 & 0.92 & 1.28 & 0.212 \\
\hline C20:1 & $0.15^{\mathrm{a}}$ & $0.05^{\mathrm{b}}$ & 0.034 \\
\hline $\mathrm{C} 20: 2$ & 0.07 & 0.10 & 0.024 \\
\hline $\mathrm{C} 20: 4$ & 0.30 & 0.23 & 0.046 \\
\hline C20:5n-3 & 0.23 & 0.17 & 0.39 \\
\hline $\mathrm{C} 22: 2$ & 0.12 & 0.07 & 0.030 \\
\hline$C 22: 3 n-3$ & $0.10^{\mathrm{a}}$ & $0.04^{\mathrm{b}}$ & 0.014 \\
\hline $\mathrm{C} 22: 4$ & 0.71 & 0.54 & 0.072 \\
\hline $\mathrm{C} 22: 5 \mathrm{n}-3$ & 0.39 & 0.35 & 0.049 \\
\hline C22:6n-3 & 0.27 & 0.22 & 0.035 \\
\hline
\end{tabular}

${ }^{\mathrm{a}, \mathrm{b}}$ Means in the same row with different superscripts $\operatorname{differ}(P<$ $0.05)$.

${ }^{1} \mathrm{LOT}=$ corn silage-alfalfa hay mix plus $640 \mathrm{~g}$ of fish oil and sunflower oil $(1: 3 \mathrm{wt} / \mathrm{wt}) . \mathrm{PAS}=$ pasture plus $640 \mathrm{~g}$ of fish oil and sunflower oil $(1: 3 \mathrm{wt} / \mathrm{wt})$.

Khanal et al., 2005; Bargo et al., 2006; Couvreur et al., 2006). It has been shown that when calcium-salts of FA (30\% linoleic acid) partially replace corn in the grain mix supplemented to grazing dairy cows, milk cis-9, trans-11 CLA increases by $71 \%$ and by $366 \%$ when compared with cows fed TMR (Schroeder et al., 2003). Khanal et al. (2005) also showed that cows that were grazed on pasture and received $3.2 \mathrm{~kg} / \mathrm{d}$ of grain mix containing full fat extruded soybeans had $211 \%$ more cis-9, trans11 CLA in their milk when compared with cows fed 
TMR. When fresh cut grass replaced corn silage in cows diet at $0,30,60$, and $100 \%$, milk cis-9, trans-11 CLA averaged $0.48,0.54,1.21$, and $1.65 \mathrm{~g} / 100 \mathrm{~g}$ of total FA, respectively (Couvreur et al., 2006). It has been suggested that the greater concentration of cis-9, trans-11 CLA in milk fat from grazing cows may result from the increase in linolenic acid intake (Ribeiro et al., 2005; Bargo et al., 2006), and subsequently, the increase in amounts of VA available postruminally for cis-9, trans11 CLA synthesis by $\Delta^{9}$-desaturase. Couvreur et al. (2006) reported that milk trans C18:1 (VA in particular) linearly increased as the proportion of fresh cut grass in cows diet increased from 0 to 30,60 , and $100 \%$ of DM of forage. Loor et al. (2004) noted that compared with a control diet, adding linseed oil to dairy cows' diets (65:35 forage to concentrate) at $3 \%$ of DM increased the duodenal flow of C18:0 and trans C18:1 with VA accounting for $43 \%$ of trans C18:1. Additionally, when cows managed in confinement or on pasture were fed $500 \mathrm{~g} / \mathrm{d}$ of soybean oil, milk C18:0, trans C18:1 and cis9, trans-11 CLA contents were greater with pasture than the confinement cows (Boken et al., 2005). In this study, it is unlikely that the greater cis-9, trans-11 CLA concentration in milk fat with the PAS diet resulted from the increase in linolenic acid intake because the concentrations of trans $\mathrm{C} 18: 1$ and C18:0 in milk fat were similar for both diets (Table 3). The underlying causal mechanism(s) by which grazing increases milk cis-9, trans-11 CLA remains unclear, but it is evident from this study that unknown pasture constituents create condition(s) in the rumen that favor higher ratio of VA to trans-10 C18:1, and therefore, increase VA availability for cis-9, trans-11 CLA synthesis by delta9 desaturase. When dairy cows were fed TMR containing a blend of FO and SFO, Shingfield et al. (2006) showed that cis-9, trans-11 CLA in milk fat reached its highest concentration by $\mathrm{d} 5$ of oil supplementation, but then declined thereafter as a result of trans-10 C18:1 replacing VA as the predominant FA. However, such shift was not observed when a blend of FO and SFO was added to grazing dairy cows' diets (AbuGhazaleh and Holmes, 2007).

Some of the variation in milk cis-9, trans-11 CLA response between the 2 diets tested in this study could also be attributed to differences in $\Delta^{9}$-desaturase activity. Product to substrate ratios of some FA represent a $\Delta^{9}$-desaturase index and can serve as a proxy for $\Delta^{9}$ desaturase activity (Baumgard et al., 2002). There are 4 major products of $\Delta^{9}$-desaturase activity in the mammary gland: C14:1, C16:1, cis-9 C18:1 and cis-9, trans11 CLA, which are produced from C14:0, C16:0, C18:0, and VA, respectively. The $\Delta^{9}$-desaturase index was not different between the 2 diets (Table 5), suggesting simi-
Table 5. Effect of treatment diets on delta-9 desaturase index

\begin{tabular}{llll}
\hline & \multicolumn{3}{c}{ Diet $^{1}$} \\
\cline { 2 - 3 } Item & LOT & PAS & SEM \\
\hline C14:1/C14:0 & 0.13 & 0.10 & 0.013 \\
C16:1/C16:0 & 0.08 & 0.07 & 0.006 \\
C18:1 cis-9/C18:0 & 2.53 & 2.37 & 0.186 \\
cis-9, trans-11 CLA/VA & 0.37 & 0.38 & 0.035 \\
\hline
\end{tabular}

${ }^{1} \mathrm{LOT}=$ corn silage-alfalfa hay mix plus $640 \mathrm{~g}$ of fish oil and sunflower oil (1:3 wt/wt); PAS = pasture plus $640 \mathrm{~g}$ of fish oil and sunflower oil $(1: 3 \mathrm{wt} / \mathrm{wt})$.

${ }^{2} \mathrm{CLA}=$ conjugated linoleic acid; $\mathrm{VA}=$ vaccenic acid.

lar $\Delta^{9}$-desaturase activity for the LOT and the PAS cows.

\section{CONCLUSIONS}

Milk yield was lower with pasture feeding system compared with the confinement feeding system. However, the feeding system had no effect on milk fat and protein percentages. Milk FA profile response to FO and SFO supplementation varied by feeding system. Fish oil and SFO supplementation resulted in higher milk VA, cis-9, trans-11 CLA and lower trans-10 C18:1 concentrations and yields in pasture-fed cows compared with confinement-fed cows. The lower cis-9, trans-11 CLA concentration in milk from the confinement-fed cows resulted from trans-10 C18:1 replacing VA as the predominant trans C18:1 isomer.

\section{REFERENCES}

AbuGhazaleh, A. A., and L. Holmes. 2007. Diet supplementation with fish oil and sunflower oil to increase conjugated linoleic acid levels in milk fat of partially grazing dairy cows. J. Dairy Sci. 90:2897-2904.

AbuGhazaleh, A. A., and B. N. Jacobson. 2007. Production of trans C18:1 and conjugated linoleic acid in continuous culture fermenters fed diets containing fish oil and sunflower oil with decreasing levels of forage. Animal 1:660-665.

AbuGhazaleh, A. A., and T. C. Jenkins. 2004. Short Communication: Docosahexaenoic acid promotes vaccenic acid accumulation in mixed ruminal cultures when incubated with linoleic acid. J. Dairy Sci. 87:1047-1050.

AbuGhazaleh, A. A., M. B. Riley, E. E. Thies, and T. C. Jenkins. 2005. Dilution rate and $\mathrm{pH}$ effects on the conversion of oleic acid to trans C18:1 positional isomers in continuous cultures. J. Dairy Sci. 88:4334-4341.

AbuGhazaleh, A. A., D. J. Schingoethe, A. R. Hippen, and K. F. Kalscheur. 2003. Milk Conjugated linoleic acid response to fish oil supplementation diets differing in fatty acid profiles. J. Dairy Sci. 86:944-953.

AbuGhazaleh, A. A., D. J. Schingoethe, A. R. Hippen, and L. A. Whitlock. 2002. Feeding fish meal and extruded soybeans enhances the conjugated linoleic acid content of milk. J. Dairy Sci. 85:624-631.

Association of Official Analytical Chemists. 1997. Official Methods of Analysis. 16th ed. AOAC Intl., Gaithersburg, MD.

Bargo, F., J. E. Delahoy, L. H. Baumgard, and L. D. Muller. 2006. Supplementing total mixed rations with pasture increase the 
content of conjugated linoleic acid in milk. Anim. Feed Sci. Technol. 131:226-240.

Bargo, F., L. D. Muller, J. E. Delahoy, and T. W. Cassidy. 2002. Performance of high producing dairy cows with three different feeding systems combining pasture or total mixed rations. J. Dairy Sci. 85:2959-2974.

Baumgard, L. H., E. Matitashvili, B. A. Corl, D. A. Dwyer, and D. E. Bauman. 2002.trans-10, cis-12 conjugated linoleic acid decreases lipogenic rates and expression of genes involved in milk lipid synthesis in dairy cows. J. Dairy Sci. 85:2155-2163.

Boken, S. L., C. R. Staples, L. E. Sollenberger, T. C. Jenkins, and W. W. Thatcher. 2005. Effect of grazing and fat supplementation on production and reproduction of Holstein cows. J. Dairy Sci. 88:4258-4272.

Casper, D. P., D. J. Schingoethe, R. P. Middaugh, and R. J. Baer. 1988. Lactational responses of dairy cows to diets containing regular and high oleic sunflower seeds. J. Dairy Sci. 71:12671274.

Couvreur, S., C. Hurtaud, C. Lopez, L. Delaby, and J. L. Peyraud. 2006. The linear relationship between the proportion of fresh grass in the cow diet, milk fatty acid composition, and butter properties. J. Dairy Sci. 89:1956-1969.

Donovan, D. C., D. J. Schingoethe, R. J. Baer, J. Ryali, A. R. Hippen, and S. T. Franklin. 2000. Influence of dietary fish oil on conjugated linoleic acid and other fatty acids in milk fat from lactating dairy cows. J. Dairy Sci. 83:2620-2628.

Griinari, J. M., and D. E. Bauman. 1999. Biosynthesis of conjugated linoleic acid and its incorporation into meat and milk in ruminants. Pages 180-200 in Advances in Conjugated Linoleic Acid Research, Volume 1. M. P. Yurawecz, M. M. Mossoba, J. K. G. Kramer, M. W. Pariza, and G. J. Nelson, ed. AOCS Press, Champaign, IL.

Holmes, L., and A. A. AbuGhazaleh. 2007. Milk cis-9, trans-11 CLA and omega-3 fatty acids response to linseed oil and fish oil supplementation when dairy cows managed under confinement or grazing system. J. Dairy Sci. 90(Suppl. 1):37. (Abstr.)

Kay, J. K., T. R. Mackle, M. J. Auldist, N. A. Thomson, and D. E. Bauman. 2004. Endogenous synthesis of cis-9, trans-11 CLA in dairy cows fed fresh pasture. J. Dairy Sci. 87:369-378.

Kay, J. K., J. R. Roche, E. S. Kolver, N. A. Thomson, and L. H. Baumgard. 2005. A comparison between feeding systems (pasture and TMR) and the effect of vitamin $\mathrm{E}$ supplementation on plasma and milk fatty acid profiles in dairy cows. J. Dairy Res. 72:322-332.

Kelly, M. L., E. S. Kolver, D. E. Bauman, M. E. Van Amburgh, and L. D. Muller. 1998. Effect of intake of pasture on concentrations of conjugated linoleic acid in milk of lactation cows. J. Anim. Sci. 81:1630-1636

Khanal, R. C., T. R. Dhiman, A. L. Ure, C. P. Brennand, R. L. Boman, and D. J. McMahon. 2005. Consumer acceptability of conjugated linoleic acid-enriched milk and Cheddar cheese from cows grazing on pasture. J. Dairy Sci. 88:1837-1847.

Kramer, J. K., V. Feller, M. E. Dugan, F. D. Sauer, M. M. Mossoba, and M. P. Yurawecz. 1997. Evaluating acid and base catalysts in the methylation of milk and rumen fatty acids with special emphasis on conjugated dienes and total trans fatty acids. Lipids $32: 1219-1228$

Lawless, F., J. J. Murphy, D. Harrington, R. Devery, and C. Stanton. 1998. Elevation of conjugated cis-9, trans-11-octadecadienoic acid in bovine milk because of dietary supplementation. J. Dairy Sci. 81:3259-3267.
Loor, J. J., F. D. Soriano, X. Lin, J. H. Herbein, and C. E. Polan. 2003. Grazing allowance after the morning or afternoon milking for lactating cows fed a total mixed ration (TMR) enhances trans11-18:1 and cis-9, trans-11 18:2 (rumenic acid) in milk fat to different extents. Anim. Feed Sci. Technol. 109:105-119.

Loor, J. J., K. Ueda, A. Ferlay, Y. Chilliard, and M. Doreau. 2004. Biohydrogenation, duodenal flow, and intestinal digestibility of trans fatty acids and conjugated linoleic acids in response to dietary forage:concentrate ratio and linseed oil in dairy cows. J. Dairy Sci. 87:2472-2485.

Onetti, S. G., R. D. Shaver, M. A. McGuire, D. L. Palmquist, and R. R. Grummer. 2002. Effect of supplemental tallow on performance of dairy cows fed diets with different corn silage:alfalfa silage ratios. J. Dairy Sci. 85:632-641.

Parodi, P. W. 1999. Conjugated linoleic acid and other anticarcinogenic agents of bovine milk fat. J. Dairy Sci. 82:1339-1349.

Piperova, L. S., J. Sampugna, B. B. Teter, K. F. Kalscheur, M. P. Yurawecz, Y. Ku, K. M. Morehouse, and R. A. Erdman. 2002. Duodenal and milk trans octadecenoic acid and conjugated linoleic acid (CLA) isomers indicate that postabsorptive synthesis is the predominant source of cis-9-containing CLA in lactating dairy cows. J. Nutr. 132:1235-1241.

Ribeiro, C. V. D. M., S. K. R. Karnati, and M. L. Eastridge. 2005. Biohydrogenation of fatty acids and digestibility of fresh alfalfa or alfalfa hay plus sucrose in continuous culture. J. Dairy Sci. 88:4007-4017.

Robertson, J. B., and P. J. Van Soest. 1981. The detergent system of analysis and its application to human foods. Pages 123-129 in the Analysis of Dietary Fiber. W. P. T. James and O. Theander, ed. Marcel Dekker, New York, NY.

Schroeder, G. F., J. E. Delahoy, I. Vidaurreta, F. Bargo, G. A. Gagliostro, and L. D. Muller. 2003. Milk fatty acid composition of cows fed a total mixed ration or pasture plus concentrates replacing corn with fat. J. Dairy Sci. 86:3237-3248.

Sehat, N., M. P. Yurawecz, J. A. G. Roach, M. M. Kramer, and Y. Ku. 1998. Silver-ion high performance liquid chromatography separation and identification of conjugated linoleic acid isomers. Lipids 33:217-221.

Shingfield, K. J., C. K. Reynolds, G. Hervas, J. M. Griinari, A. S. Grandison, and D. E. Beever. 2006. Examination of the persistency of milk fatty acid composition responses to fish oil and sunflower oil in the diet of dairy cows. J. Dairy Sci. 89:714-732.

Shingfield, K. J., C. K. Reynolds, B. Lupoli, V. Toivonen, M. P. Yurawecz, P. Delmonte, J. M. Griinari, A. S. Grandison, and D. E. Beever. 2005. Effect of forage type and proportion of concentrate in the diet on milk fatty acid composition in cows given sunflower oil and fish oil. Anim. Sci. 80:225-238.

Van Soest, P. J., J. B. Robertson, and B. A. Lewis. 1991. Methods for dietary fiber, neutral detergent fiber, and non-starch polysaccharides in relation to animal nutrition. J. Dairy Sci. 74:35833597.

White, S. L., J. A. Bertrand, M. R. Wade, S. P. Washburn, J. T. Green, Jr., and T. C. Jenkins. 2001. Comparison of fatty acid content of milk from Jersey and Holstein cows consuming pasture or a total mixed ration. J. Dairy Sci. 84:2295-2301.

Whitlock, L., D. J. Schingoethe, A. R. Hippen, K. F. Kalscheur, R. J. Baer, N. Ramaswamy, and K. M. Kasperson. 2002. Fish oil and extruded soybeans fed in combination increase CLA in milk of dairy cows more than when fed separately. J. Dairy Sci. 85:234-243. 